\title{
Effectiveness of Guided Inquiry Laboratory-Based Module and Indicator of Analytical Thinking Skills in the Matter of Respiratory System in Senior High School
}

\author{
Wahyu Prihmardoyo ${ }^{1}$, Sajidan $^{1}$, Maridi $^{1}$ \\ ${ }^{1}$ Faculty of Teacher Training and Education, Sebelas Maret University \\ Email: wahyupm007@gmail.com
}

\begin{abstract}
This research was purposed to knowing the effectiveness of module which is based on guided inquiry laboratory method in order to increase the analytic thinking skill toward respiration system matery of XI MIPA at Senior High School 2 Sragen. This research was used the research and development (R\&D) method refers to Borg ang Gall model which have been modified into 9 stage; 1) researching and collecting data, 2) planning, 3) developing the draft of product, 4) testing the first experiment field, 5) revising the first experiment field result, 6) doing the experiment field, 7) completing the result of experiment field product, 8) testing the implementation field, 9) completing the result of product. The analysis data used during the research development was descriptive, properness of the module based on scoring the criteria, and thinking skill analysis. The biology module based on guided inquiry laboratory (GIL) was effectively to empower the aspect of analytic thinking skill in order to formulate the objective and make the result.
\end{abstract}

Keywords: learning module guided inquiry laboratory; module which is based on guided inquiry laboratory; analytic thinking skill; respiratory system

\section{INTRODUCTION}

Thinking is a natural process that is owned by students to build concepts or ideas in students. Thinking skills are needed in the $21^{\text {st }}$ century to prepare students for more complex problems with increased globalization in different sectors [1]. A study conducted by Griffin et al [2] suggests substantial changes in abstract task improvements (tasks or jobs requiring high-level thinking skills, eg doctors, designers, scientists, employers, etc.) and Decreased routine task (work that becomes routine, for example: administration, etc.). The thinking skills needed in the $21 \mathrm{st}$ century according to the 21 st century learning framework are, among other things, high-order thinking skills.

High-level thinking skills are part of the thinking process that needs to be built from the thinking stage of remembering, understanding, applying, analyzing and then making decisions by making criteria of judgment, criticism and input even to providing solutions. Changes in mindset and learning patterns are implemented to foster higher-order thinking skills in students [3]. Higher-order thinking or HOTS (Higher Order Thinking Skills) is understanding the facts, concepts, principles, procedures and performing analysis, evaluation and creating. High-level thinking skills in Bloom's revised taxonomy have three aspects: analysis, evaluation, and 
creating. Aspects of analysis is to describe a problem or object to its elements and determine the linkage between elements. The evaluation aspect is to make a consideration based on existing criteria and standards. The aspect of creating (creating) is to combine several elements into a unified form [4]. So in this study focused only on analytic thinking skills, where this ability is the lowest level of highlevel skill level. This is reinforced by the law of practice proposed by Thorndike, that learning begins at an easy level gradually toward the difficult, starting from the simple gradually toward the complex [5].

The importance of analytic thinking skills for students is that students are able to process the information or data it acquires for later can be linked and used in everyday life [6]. This analytic thinking skill is important because students with analytic thinking skills will be able to identify nearby events, connect and combine data from different sources and draw logical conclusions and sharpen students thinking [7]. Based on field observations, less learning process activities are encouraged to develop analytical skills. The process of learning in the classroom is more directed to the ability of students to remember and understand information without being required to analyze the information it remembered to connect it with everyday life.

The result of observation in SMA Negeri 2 Sragen shows the low of science mastery which is closely related to the quality of learning. Based on the analysis of 8 National Standards of Education covering content standards, process standards, graduation competency standards, educator standards and education personnel as well as assessment standards show that the gap in Standard 1 is 2.78\%; Standard 2 is $4.64 \%$; Standard 3 of $2.87 \%$; Standard 4 of $1.48 \%$; Standard 5 of $0.47 \%$, Standard 6 of $0.94 \%$; Standard 7 by $0.01 \%$; and Standard 8 of $3.25 \%$ [8]. The data shows that in standard 2 the standard process has a gap that is high. The existence of this gap can be concluded that less maximal implementation of learning process.

The lack of quality in learning affects the achievement of low learning outcomes. One measure of learning outcomes is a national exam. The result of national exam from the Badan Standarisasi Nasional data on the biology subjects of SMA Negeri 2 Sragen in 2011/2012 show on the material structure and function of organs in the respiratory system the average value obtained is 56.25 while for the national average of 64.33 ; The results of the national exam year 2012/2013 are also still below the national average of 62.79 while the average national value of 70.71 ; And the results of the national exam year 2013/2014 are still below the national average, which is 38.17 while the national average is 42.89; The results of national exam 2014/2015 year amounted to 46.45 while the national average of 46.92 where this value is below the $K K M$ (minimum exhaustiveness criteria) is 75.00. From the national exam results data that are still below this standard then there should be improvements in the learning process in the classroom. One of the efforts in improving learning outcomes is by applying the appropriate learning model to the curriculum. For the 2013 curriculum one of the models that can be used is the inquiry learning model [9].

Inquiry learning is divided into several levels, namely discovery learning, interactive demonstration, inquiry lesson, laboratory inquiry, real-worlds application and hypothetical inquiry [10]. The inquiry learning model has the advantage of supporting its learning syntax in improving student ability of the science process. Learners with intellectual abilities at senior high school and university are more appropriate using laboratory inquiry level until hypothetical inquiry [11]. Level 
inquiry laboratory by Wenning again divided into 3 levels: guided inquiry laboratory, bounded inquiry laboratory and free inquiry laboratory.

The appropriate level which was used in class XI MIPA SMA Negeri 2 Sragen is guided inquiry laboratory level. This is supported by the results of the ability tests berinkuiri given in the class XI MIPA SMA Negeri 2 Sragen showed the achievement on several levels. Data acquisition at several levels are as follows: 1) Inquire level one (discovery learning) with the acquisition of the percentage of the average value of $86.5 \%$; 2) Inquiri level two (interactive demonstration) with the acquisition of percentage of average value of $81.9 \%$; 3) Inquiry level 3 (inquiry lesson) gets percentage of average value equal to $76.5 \%$; 4) Inquiry level four (inquiry laboratory) on Sub Guided Inquiry Laboratory get the percentage of the average value of $62.3 \%$. Based on the results of the level of inquiry tests, the results obtained at level one, level two and level three are included in the good category, while at level four the students' inquiry skills are in poor category. From the data obtained learners are ready to use guided inquiry laboratory level as the appropriate learning model used in the class.

The guided inquiry laboratory model has a syntax of observation (observation, designing experiments and defining the relationship of variables), manipulation, generalization (recording experimental results and communicating), verifying (presenting findings and drawing class conclusions) and applications (applying learning in everyday life) [12]. The application of biological learning using guided inquiry laboratory model is expected to be a teacher's way to improve analytic thinking skills. In addition to learning models, teaching materials are important components that support the learning process.

The learning process will run more optimal when maximizing all teaching materials that support learners. Teaching materials as an independent training tool help learners to learn independently outside the classroom without or with the necessary help from teachers [13]. The teaching materials used by learners in the Curriculum 2013 are the books of learners. A good textbook should be able to improve students' high-order thinking skills, especially the $\mathrm{C} 4$ sphere or analytic thinking skills [14]. To improve the quality of learning can be done from various aspects of learning variables. One aspect that is considered appropriate and relevant to the above problems is the application of individual learning, which gives confidence in the individual's ability to learn independently. One of the individual learning models that are now developing is the use of modular learning systems. The module learning system will make learning more efficient, effective, and relevant [15]. Compared with conventional learning that tends to be classical and implemented face-to-face, module learning has an advantage [16].

Based on the results of teaching materials analysis at SMAN 2 Sragen it is known that the percentage of suitability of books used by students to the curriculum of 2013 include systematic aspects of writing is 34\% not appropriate and 66\% is appropriate, aspects of material presentation 66\% not appropriate and $34 \%$ is appropriate, $50 \%$ is not suitable and 50\% is in accordance with the standards of curriculum 2013. Analysis of teacher handbook in SMAN 2 Sragen known percentage of learning planning aspect $68 \%$ not appropriate and $32 \%$ is appropriate, $73 \%$ assessment of the learning aspect is not appropriate and $27 \%$ is appropriate With the standards of the 2013 curriculum. 
The results of interviews with teachers show students difficult to understand the material of the respiratory system when taught and teachers are always difficult to teach because the material is so many and complex. The low absorption power of the UN respiratory system material as a result of the students can not understand the material. The guided inquiry laboratory-based module developed on the respiratory system material is expected to help students learn meaningfully because the material content is developed into analytic thinking skills, so the students' views on the respiratory system materials change from rote to comprehension, and students are able to find concepts on the respiratory system $[17,18]$.

\section{LITERATURE REVIEW}

\section{Teaching Module}

The emergence of the term module based on the idea of individual differences in students who need attention in the learning process. Modules are often encountered with other terms, such as learning activity packages, individualized learning packages (individual modules), learning packages. In Indonesia the term module was first presented in a meeting forum between the 8 Pioneer School Development Projects in Cibulan Bogor in February 1974 [19]. The teaching module is an independent learning package that includes a set of learning experiences that are planned and systematically designed to help students achieve learning objectives [20]. The teaching module presents activities that involve students' active learning experiences in learning activities so as to achieve effective and efficient learning objectives. The teaching module is a planned learning activity unit designed to help students learn independently in achieving learning objectives. Teach modules prepared by teachers tailored to the characteristics of students include the level of knowledge and age that aims to students understand the material presented.

\section{Guided Inquiry Laboratory (GIL) module}

Learning using the GIL model, teachers play an active role in determining the problem and the stages of the solution. Learners are confronted with relevant tasks to be solved either through group discussions or individually to be able to solve problems and draw conclusions independently [21]. Learners are oriented to the guidance and instruction of the teacher, so they can understand the concepts of the lesson through pre lab activities and leading questioning [22]. Prelab activities undertaken in GIL learning are intended to activate the initial knowledge of learners and help learners to understand the concepts and objectives of learning as well as the scientific process for conducting investigations [23]. The leading questioning activity is an activity that distinguishes the three types of inquiry on top. Leading questioning on GIL learning is a question that leads learners in preparing experimental steps to be performed. The role of teachers in asking questions should be based on good inquiry skills, eg by providing enough waiting time for learners to formulate, process and answer questions [24]. This is in line with the assertion that GIL requires teachers to direct learners to the implementation of experimental design [25]. 


\section{Analytical Thinking Skills}

Analytical thinking is the ability to identify events around. Collecting and analyzing information, linking and combining data from different sources, thus arriving at a logical conclusion [7]. Analytical thinking is the ability to decompose complex components into simpler parts and to make comparisons and arrangements to reconnect parts of the constituent components into one meaningful component, thus arriving at a comprehensive conclusion that sharpens the thinking power of the students [26]. Analytical thinking is the process of elaborating complex material structures into smaller sub-materials, identifying relationships between sub-materials, and the relation of each sub-material with a complex material structure as a whole [4]. Analytical thinking is the process of thinking to describe a complex subject matter into its constituent parts, identify patterns of relationships between the parts generated so as to obtain alternative solutions and decisions appropriate to solve the problem [27]. Analytical thinking is the ability to understand the overall relationship or part of a component and causal pattern generated, sorting, categorizing, comparing differences and similarities between components, understanding the workings of a component or component parts so that it works in an organized manner, and how to obtain information in the form of data, graphics, pictures and maps [28].

\section{RESEARCH METHODOLOGY}

This research uses reasearch and development (R \& D) method based on Borg Gall model which has been modified into 9 stages: 1) research and data collection, 2) planning, 3) product draft development, 4) initial field test, 5) Revise test results, 6) field trials, 7) improvements to the product of field test, 8) field implementation test, 9) final product refinement. Data analysis used during development is descriptive analysis, module feasibility analysis based on criteria score, and analysis of student analytic thinking skill test. Methods of data retrieval used were: interviews, questionnaires, observations and test questions. The subjects of the research are the students of class XI MIPA SMA Negeri 2 Sragen, the time of the research is the even semester of the academic year 2016/2017.

\section{RESULT AND DISCUSSION}

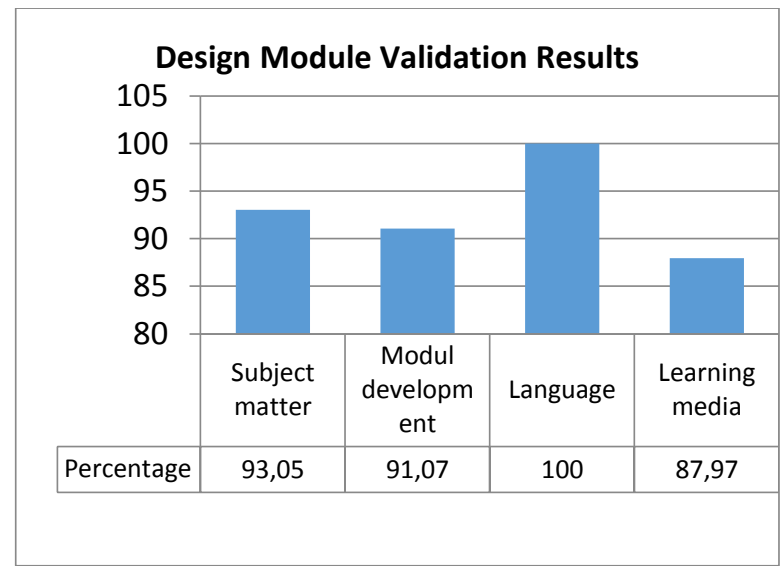

Figure 1. Percentage of expert validation assessment 
The results of the initial product development stage is a guided inquiry laboratory (GIL) model based module on the respiratory system material to improve students' critical thinking skills. Module GIL-based based on learning objectives, materials, activities and questions of evaluation is the development of GIL learning syntax and aspects of critical thinking skills on the respiratory system material. The GIL model-based module was developed with a module confirmation book (teacher module). The result of the validation stage of the student module design is obtained as shown in figure 1 .

Figure 1 shows that the material awareness, module development, language, and learning tools of GIL model-based modules in the respiratory system materials are in line with the target, as indicated by the validation of the material experts obtaining a grade of $93.05 \%$ indicating excellent qualifications, The module obtains a $91.07 \%$ rating indicating excellent qualification, validation of the language gets $100 \%$ indicates excellent qualification, as well as expert device expert validation get the value $87.97 \%$ indicates excellent qualification.

Furthermore, field tests are limited to obtain the results as in Figure 2.

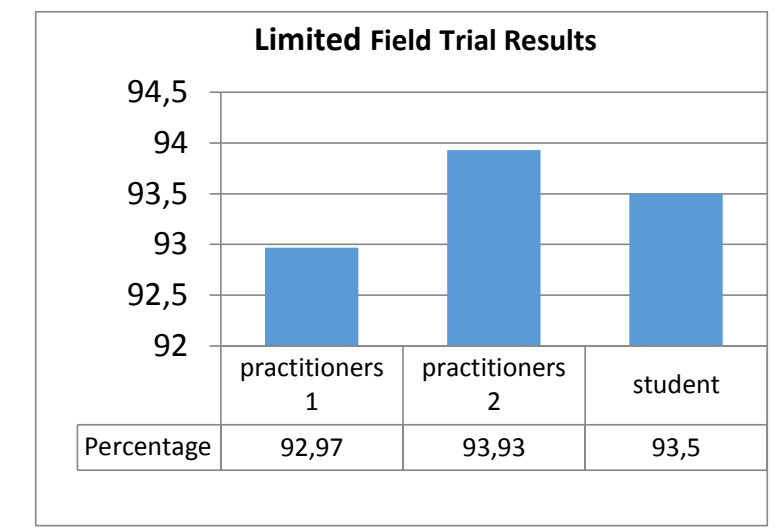

Figure 2. Histogram field trial assessment is limited

Practitioners and small groups of users concluded that GIL model-based modules on respiratory system materials scored $92.97 \%$ and $93.93 \%$ indicating excellent qualifications. Based on the assessment the students scored $93.5 \%$ which showed excellent qualifications based on the small group assessment of students, so that it can proceed to the operational field trials to determine the effectiveness of the module after correcting the shortcomings of the education practitioners and small groups.

Data analysis of students 'critical thinking skill is done on pre-test and post-test data on students' critical thinking skill aspect in class of module and control class presented in table I. 
Table I. .DATA VALUE ASPECT OF STUDENTS' ANALYTIC THINKING SKILL IN TREATMENT CLASS AND EXISTING CLASS

\begin{tabular}{|clcccc|}
\hline $\begin{array}{c}\text { Student's } \\
\text { Learning } \\
\text { Research } \\
\text { Data }\end{array}$ & Class & $\begin{array}{c}\text { Maximum } \\
\text { Value }\end{array}$ & $\begin{array}{c}\text { Minimum } \\
\text { Value }\end{array}$ & Average & $\begin{array}{c}\text { Deviation } \\
\text { Standard }\end{array}$ \\
\hline Pretest & Existing & 60.00 & 25.00 & 42.20 & 9.80 \\
& Treatment & 55,00 & 20.00 & 42.71 & 8.07 \\
\hline Posttest & Existing & 80.00 & 60,00 & 68.20 & 5.18 \\
& Treatment & 80.00 & 15.00 & 52.50 & 15.46 \\
\hline N-gain & Existing & 0.64 & 0.11 & 0.43 & 0.14 \\
& Treatment & 0.63 & -0.50 & 0.15 & 0.30 \\
\hline
\end{tabular}

Based on table 1 can be seen an increase in average students' analytic thinking skills after learning in the higher treatment class of the existing class. A large standard deviation value (from mean / mean) indicates a large variation, and vice versa [29]. That means that the high posttest mean in the low treatment grade and low standard deviation indicates the distribution of student scores closer to the mean, the decrease in the standard deviation with an increase in the student's average score of the pretest and posttest values indicates that the expected scaffolding is Implemented, so that the average student is able to get a high score.

The value of pretest and posttest is calculated level of increase of learning result to know effectiveness of learning with module. The formula used is a normalized gain formula. Based on the result of normalized gain calculation obtained average increase of learning result of class of treatment from 25 students is 0,43 . According to the value criteria shows the increase in student learning outcomes in the category of being, while the existing class known $\mathrm{N}$-gain data of 0.15 with low improvement criteria. After the calculation of normalized gain values, then do the prerequisite test and further tests [30]. A summary of the results of $\mathrm{N}$-gain value analysis of learning outcomes is presented in Table II.

TABLE II. SUMMARY OF N-GAIN VALUE TEST RESULTS ANALYTIC THINKING SKILLS

\begin{tabular}{|cccccc|}
\hline $\begin{array}{c}\text { Study Result } \\
\text { Data }\end{array}$ & Class & Avera & $\begin{array}{c}\text { Normality } \\
\text { Test (Sig) }\end{array}$ & $\begin{array}{r}\text { Homogen } \\
\text { eity Test }(\text { Sig) }\end{array}$ & $\begin{array}{c}\text { T-Test } \\
\text { (Sig) }\end{array}$ \\
\hline$N$-gain & $\begin{array}{c}\text { Experiment } \\
\text { Existing }\end{array}$ & 0.430 & $0.200>0.050$ & $0.001<0.050$ & $0.000<0.050$ \\
\hline
\end{tabular}

N-gain value data from class XI MIPA 2 and XI MIPA 4 were analyzed by normality and homogeneity prerequisite test in order to further test to test the effectiveness of GIL-based module in improving analytic thinking skill. Based on Table 26 it shows that the data of the treatment class gain and the existing class are normally distributed but not homogeneous, so that it is followed by the parametric test of t-test, so that sig $(0.000<0.05)$ means that the two data are significantly different. The N-gain data of the treatment class is higher than the existing class, so it can be concluded that GIL-based modules more effectively improve students' analytic thinking skills.

An analysis of the per-aspect improvement of students' analytic thinking skills was also conducted to determine the effectiveness module of GIL-based in improving every aspect. The analysis was done based on the calculation of question items on the pretest and posttest of students based on analytic thinking skills. A 
summary of the per-aspect improvement of analytic thinking skills is presented in Table III

Based on table 3 can be seen the effectiveness of GIL model-based module in improving students' analytic thinking skills. Improvement occurs in every aspect. Average increases with high criteria occur on the aspect of formulating goals and making conclusions, and improvements with criteria are taking place on aspects of using information, making assumptions, using concepts, and implicating.

TABLE III. RESULT OF ANALYSIS IMPROVEMENT PER-ASPECT OF ANALYTIC THINKING SKILL OF STUDENT OF TREATMENT CLASS

\begin{tabular}{|lcccc|}
\hline \multirow{2}{*}{ Indicators } & \multicolumn{4}{c|}{ Student's Value } \\
\cline { 2 - 5 } & $\mathbf{S}_{\text {pre }}$ & $\mathbf{S}_{\text {post }}$ & $\boldsymbol{N}$-gain & Criteria \\
\hline Formulating Goals & 45.33 & 84.00 & 0.71 & High \\
Using Information & 47.00 & 71.00 & 0.45 & Average \\
Making Assumsion & 56.00 & 70.00 & 0.32 & Average \\
Making Concept & 10.67 & 53.33 & 0.48 & Average \\
Implification & 28.00 & 50.67 & 0.31 & Average \\
Making Decission & 58.67 & 88.00 & 0.71 & High \\
\hline
\end{tabular}

The Guided Inquiry Laboratory (GIL) based module on the respiratory system material is effective in improving students' analytic thinking skills. Analytical thinking skills include one of the higher-order thinking skills ${ }^{[31]}$. Students who learn to experiment in laboratories and conduct experiment-based experiments have better high-level thinking skills [32]. Other supporting studies argue that in the discovery of inquiry can improve students' thinking ability [33, 34]. Inquiry or discovery learning activities can be done with Guided Inquiry Laboratory (GIL) guidelines [35, 36].

The results of operational field trials in this study include data analytical thinking skills of students. Data of students' analytic thinking skill was obtained from pretest and posttest, then analyzed the value of $\mathrm{N}$-gain to know its improvement / effectiveness [37]. Based on table 3, the t-test shows that the GIL model-based module is effective in improving students' analytic thinking skills, and further analysis is done to determine their effectiveness in each aspect [38]. Higher criterion enhancement occurs on the aspect of formulating goals and making conclusions, and improvements with criteria are taking place on the aspects of using information, making assumptions, using concepts, and implicating.

Improving students' analytic thinking skills during the lessons answered the effectiveness of GIL-based learning modules. The first GIL syntax of observation is to identify problems arising from the surrounding phenomenon [34], this syntax can trace aspects of the ability to formulate goals. The second syntax of GIL manipulation, ie the stages when students experiment on hypotheses or design and implement hypothesis testing methods [11], this second syntax can trap aspects of using information and making assumptions. The third syntax of generalization is that students perform observations of experiments recording their findings [18], this syntax trains aspects of concept using. The verification syntax is that students communicate their findings to other groups interested in the evidence $[39,40]$, this syntax trains the analytic thinking skills of the implicating aspects. The fifth syntax 
of the application is the students collect the conclusions and apply them in solving the problems given by the teacher, this syntax trains the analytic thinking skill of the aspect to make the conclusion $[41,42]$.

Analytical thinking skills are one part of high-order thinking skills [31,43]. Students can develop high-level thinking skills through case studies and articles to find problems to be solved in learning [34]. Through articles it provides another alternative for teachers not to teach conventionally [18]. This can give students the opportunity to acquire thinking skills other than conceptual knowledge. The impact of companions is interesting cases and articles that arouse students 'curiosity, as well as develop students' scientific and communication reasoning [43]. Another supportive study is that high-level thinking can be trained by solving a problem [44]. Teachers are required to provide more space to develop logical, systematic and creative thinking skills to produce logical, rational, and independent individuals [4547].

\section{CONCLUSION}

Guided Inquiry Laboratory-based biology modules are effective for improving analytic thinking skills in terms of formulating objectives and drawing conclusions with high value criteria and effectively improving aspects of using information, making assumptions, using concepts, and implicating with medium value criteria..

\section{REFERENCE}

[1] Kereluik, K., Mishra, P., Fahnoe, C., \& Terry, L. (2013). What knowledge is of most worth: Teacher knowledge for 21st century learning. Journal of Digital Learning in Teacher Education, 29(4), 127-140.

[2] Griffin, P., McGaw, B., \& Care, E. (2012). Assessment and teaching of 21st century skills. Dordrecht: Springer.

[3] Sabar, I. Y. (2014). Pengembangan Modul Untuk Meningkatkan Higher Order Thinking Skill PadaMata Kuliah Strategi Pembelajaran untuk Mahasiswa Program Studi Teknologi Pendidikan FIP-UNESA. Jurnal Mahasiswa Teknologi Pendidikan, 2(2).

[4] Anderson, L. W., Krathwohl, D. R., \& Bloom, B. S. (2001). A taxonomy for learning, teaching, and assessing: A revision of Bloomś taxonomy of educational objectives. Allyn \& Bacon .

[5] Thorndike, E. L. (1908). The Effect of Practice in the Case of a Purely Intellectual Function. The American Journal of Psychology, 19(3), 374-384.

[6] Pally, M. (2001). Skills development in'sustained'content-based curricula: Case studies in analytical/critical thinking and academic writing. Language and Education, 15(4), 279-305.

[7] Elder, L., \& Paul, R. (2007). The Thinkerś Guide to Analytic Thinking: How to Take Thinking Apart and what to Look for when You Do: the Elements of Thinking and the Standards They Must Meet. California: Foundation for Critical Thinking. Retrieved from www.criticalthinking.org

[8] Badan Standarisasi Nasional Pendidikan. (2015). Pamer Ujian Nasional. Jakarta: Kementerian Pendidikan dan Kebudayaan.

[9] Sugiyanto, Sunarno, W., \& Prayitno, B. A. (2013). Pengembangan Modul Berbasis Inkuiri Terbimbing Disertai Multimedia Pada Materi Keanekaragaman Makhluk Hidup di SMPN 1 Kendal Kabupaten Ngawi. BIOEDUKASI Volume 6, Nomor 1, 6, 22-23. Retrieved from https://jurnal.uns.ac.id/bioedukasi/article/download/3910/3384

[10] Wenning, C. J. (2011b). The Levels of Inquiry Model of Science Teaching Wenning (2010) 
for explications of real-world applications component of the Inquiry Spectrum.) A Levels of Inquiry Redux. Journal of Physics Teacher Education Online, 6(2).

[11] Nline, O., Jackson, J., \& Wenning, C. J. (2010). Levels of inquiry: Using inquiry spectrum learning sequences to teach science. Journal of Physics Teacher Education Online, 5(4).

[12] Wenning, C. J. (2011a). Experimental Inquiry in Introductory Physics Courses. Journal of Physics Teacher Education Online, 6(2), 2-8.

[13] Probosari, R. M. (2010). Stimulasi Belajar Mandiri Melalui Pengembangan Bahan Ajar Berbasis Masalah Pada Mata Kuliah Plant Embryology And Reproduction (SBI Program) Di Prodi P. Biologi FKIP UNS. Prosiding Seminar Biologi (Vol. 7, No. 1).

[14] Yuliati, L. (2013). Efektivitas Bahan Ajar IPA Terpadu Terhadap Kemampuan Berpikir Tingkat Tinggi Siswa SMP. Jurnal Pendidikan Fisika Indonesia, (9), 53-57. Retrieved from http://journal.unnes.ac.id/nju/index.php/jpfi/article/download/2580/2633

[15] Wena, M. (2013). Strategi Pembelajaran Inovatif Kontemporer . Jakarta: Bumi Aksara.

[16] Sudjoko. (1989). Keefektifan Pembelajaran Modul Dalam Pembelajaran Mata Kuliah Fisika

[17]Diraksa, T., \& Termtachatipong, P. (2009). The Development of Grade 10 Students' Analytical Thinking Ability and Learning Achievement About Heredity by Using Constructivist Theory Teaching Strategies Based on Underhill Approach .

[18] Qing, Z., Jing, G., \& Yan, W. (2010). Promoting Preservice Teachers' Critical Thinking Skills By Inquiry-Based Chemical Experiment. Procedia Social and Behavioral Sciences 2, 4597-4603.

[19] Salirawati, D. (2008). Teknik Penyusunan Modul Pembelajaran.

[20] Mulyasa, E. (2004). Kurikulum Berbasis Kompetensi: Konsep, Karakteristik, dan Implementasi. Bandung: Remaja Rosdakarya .

[21] Wenning, C. J. (2010). Levels of inquiry: Using inquiry spectrum learning sequences to teach science. Journal of Physics Teacher Education Online, 5(4), 6(2), 11-19.

[22] Luera, G. R., Otto, C. A., Zitzewitz, W., Wenning, C. J., Taylor, J., Powell, J. C., ... Park, J. C. (2005). Implementing inquiry-based instruction in the science classroom: A new model for solving the improvement-of-practice problem. Journal of Physics Teacher Education Online, 2(4), 1-30.

[23] Wenning, C. J. (2005). Levels Of Inquiry: Hierarchies Of Pedagogical Practices And Inquiry Processes. Journal of Physics Teacher Education Online, 2(3), 3-11. Retrieved from http://citeseerx.ist.psu.edu/viewdoc/download?doi=10.1.1.583.2818\&rep=rep1\&type=pdf

[24]Lawless, K. a., \& Pellegrino, J. W. (2007). Professional Development in Integrating Technology Into Teaching and Learning: Knowns, Unknowns, and Ways to Pursue Better Questions and Answers. Review of Educational Research, 77, 575-614. https://doi.org/10.3102/0034654307309921

[25]Domin, D. S. (1999). A Review of laboratory instruction styles. Journal of Chemical Education, 76(4), 543. https://doi.org/10.1021/ed076p543

[26] Bartlett.G. (2001). Systemic thinking: a simple thinking technique for gaining systemic ( situation-wide ) focus. Breakthroughs 2001: Ninth International Conference on Thinking, 114.

[27] Amer, A. (2005). Analytical thinking. Pathways to Higher Education.

[28] Ramos, J. L. S., Dolipas, B. B., \& Villamor, B. B. (2013). Higher Order Thinking Skills and Academic Performance in Physics of College Students : A Regression Analysis, (4), 48-60. Retrieved from http://www.academia.edu/download/44521473/HOTS.pdf

[29] Santoso, S. (2012). Panduan Lengkap SPSS Versi 20. Jakarta: PT Elex Media Komputindo.

[30] Hake, R. R. (1999). Analyzing Change/Gain Scores. Woodland Hills, CA. Retrieved from http://www.physics.indiana.edu/ sdi/AnalyzingChange-Gain.pdf

[31]Cottrell, S. (2011). Critical Thinking Skills: Developing Effective Analysis and Argument. London: Palgrave Macmillan.

[32] Berkmen, M. B., Murthy, A. C., \& Broulidakis, M. P. (2014). An Inquiry-Based Laboratory Module to Promote Understanding of the Scientific Method and Bacterial Conjugation. Journal of Microbiology \& Biology Education, 15(2), 321-322. https://doi.org/10.1128/jmbe.v15i2.763

[33]Ross, R. (2000). Session F1D Inquiry-Based Experiments In The Introductory Physics Session F1D (pp. 1-6).

[34] Stein, M. K., Grover, B. W., \& Henningsen, M. (1996). Building Student Capacity for 
Mathematical Thinking and Reasoning: An Analysis of Mathematical Tasks Used in Reform Classrooms. American Educational Research Journal, 33(2), 455-488. https://doi.org/10.3102/00028312033002455

[35] Brown, P. J. P. (2010). Process-oriented guided-inquiry learning in an introductory anatomy and physiology course with a diverse student population. AJP: Advances in Physiology Education, 34(3), 150-155. https://doi.org/10.1152/advan.00055.2010

[36] Wardani, S., Nurhayati, S., \& Safitri, A. (2016). The Effectiveness of the Guided Inquiry Learning Module towards Students' Character and Concept Understanding. International Journal of Science and Research, 5(6), 1589-1594.

[37] Dimitrov, D. M., \& Rumrill, P. D. (2003). Pretest-posttest designs and measurement of change. Work (Reading, Mass.), 20(2), 159-165. https://doi.org/10.1017/CBO9781107415324.004

[38] Rausch, J. R., Maxwell, S. E., \& Kelley, K. (2003). Analytic methods for questions pertaining to a randomized pretest, posttest, follow-up design. Journal of Clinical Child and Adolescent Psychology, 32(3), 467-486.

[39] Blanchard, M. R., Southerland, S. A., Osborne, J. W., Sampson, V. D., Annetta, L. A., \& Granger, E. M. (2010). Is inquiry possible in light of accountability?: A Quantitative comparison of the relative effectiveness of guided inquiry and verification laboratory instruction. Science Education, 94(4), 577-616. https://doi.org/10.1002/sce.20390

[40] Familari, M., Silva, K. B. Da, J. Rayner G., Y., Cross, A., \& Blanksby, T. (2013). Scientific inquiry skills in first year biology: building on pre-tertiary skills or back to basics? International Journal of Innovation in Science and Mathematics Education (Formerly CALLaborate International), 21(1).

[41] Abrami, P. C., Bernard, R. M., Borokhovski, E., Wade, A., Surkes, M. A., Tamim, R., \& Zhang, D. (2008). Instructional Interventions Affecting Critical Thinking Skills and Dispositions: A Stage 1 Meta-Analysis. Review of Educational Research, 78(4), 1102-1134. https://doi.org/10.3102/0034654308326084

[42] Stempfle, J., \& Badke-Schaub, P. (2002). Thinking in design teams - An analysis of team communication. Design Studies, 23(5), 473-496. https://doi.org/10.1016/S0142694X(02)00004-2

[43] Hugerat, M., \& Kortam, N. (2014). Improving Higher Order Thinking Skills among Freshmen by Teaching Science through Inquiry. Eurasia Journal of Mathematics, Science \& Technology Education, 10(5), 447-454. https://doi.org/10.12973/eurasia.2014.1107a

[44] Tajudin, N. M., \& Chinnappan, M. (2016). The Link between Higher Order Thinking Skills, Representation and Concepts in Enhancing TIMSS Tasks. International Journal of Instruction, 9(2), 199-214. https://doi.org/10.12973/iji.2016.9214a

[45] Barak, M., \& Dori, Y. J. (2009). Enhancing higher order thinking skills among inservice science teachers via embedded assessment. Journal of Science Teacher Education, 20(5), 459-474. https://doi.org/10.1007/s10972-009-9141-z

[46] Hopson, M. H., Simms, R. L., \& Knezek, G. A. (2001). Using a Technology-Enriched Environment to Improve Higher-Order Thinking Skills. Journal of Research on Technology in Education, 34(2), 109-119. https://doi.org/10.1080/15391523.2001.10782338

[47] Ma, A. W. W. (2009). Computer Supported Collaborative Learning and Higher Order Thinking Skills: A Case Study of Textile Studies. Interdisciplinary Journal of E-Learning and Learning Objects, 5, 146-167. 